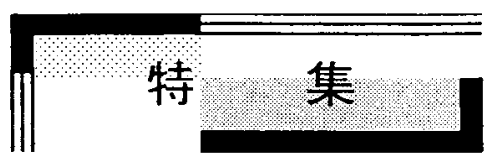

\title{
ディーゼル排ガス粒子の電気集塵技術*
}

\section{Technology of Electrostatic Precipitator for Diesel Exhaust Particle}

\author{
江 原 由 泰** \\ EHARA Yoshiyasu
}

\begin{abstract}
The particles emitted from diesel engine exhaust have low resistive in nature and extremely small in the range of 70-120 nanometers. These particles are penetrated into an alveolus and extremely harmful to human health. These particles are generated from various emissions such as diesel automobiles, marine engines, power generation engines, and construction diesel machines. These particulates also exist in tunnel or underground parking. An electrostatic precipitator has been extensively used for the collection of these particles. In the present technical report, the technology of electrostatic precipitator on diesel exhaust particle was explained.
\end{abstract}

Keywords: Electrostatic precipitator, Diesel exhaust particle, Corona discharge, Reentrainment, Electrohydrodynamics

\section{1. はじめに}

大気污染物質の中には $\mathrm{NOx}$ や $\mathrm{SOx} 、 \mathrm{CO}_{2}$ のよ うなガス状物質の他に、粒子状污染物質がある。 大気中の粒子状物質には粒径が大きく短時間に 地上に降下寸る煤じんと、粒径が小さく軽いので 長時間大気中に浮遊する浮遊粒子状物質

(Suspended Particulate Matter: SPM) とがある。 降下煤塵は健康的には大きな問題はないが、SPM は肺や気管支に入り呼吸器疾患の原因になるの で、環境的に問題となる物質である。SPM の主 な発生源は各種のボイラーや自動車からの排ガ スである。

自動車排ガス規制は段階的に厳しくなり、ガ ソリン車ではエンジンの改良や三元触媒の適用 により、大気污染物質の低減化は進んでいる。一 方、ディーゼル車においてもエンジンの改良や燃 料噴射システムであるコモンレールの導入によ り燃焼効率も改善され、ディーゼルパティキュレ ートフィルタの実用化により、PM の低減が図ら れつつある。
ディーゼルエンジンから排出されるPMの粒径 分布は Fig. 1 に示すように、質量分布では 200〜 $300 \mathrm{~nm}$ に極大を持つ。しかし、粒子数分布で見 るとナノ粒子が圧倒的に多い。粒子が小さければ 小さいほど呼吸器系の深部まで吸入されるため、 粒径に応じて呼吸器系の各部位に沈着し、人の健 康に大きな影響を与える。約 $2 \mu \mathrm{m}$ 以下の PM は 呼吸器系の最深部である肺領域の気管支枝や肺

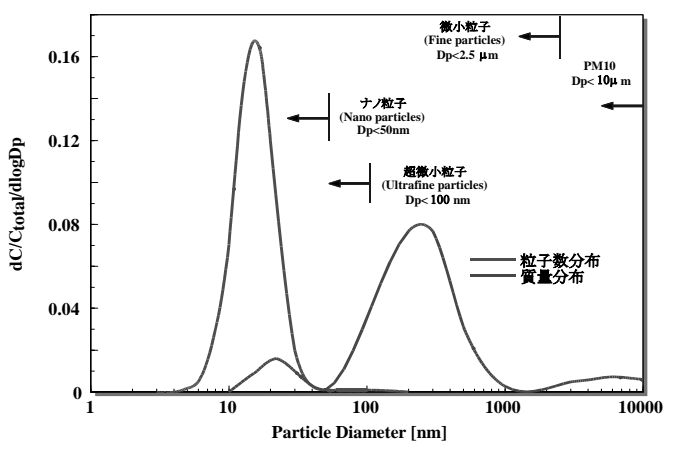

Fig. 1 Distribution of diesel exhaust Particle.

* 2013.8.1 受付

** 東京都市大学工学部電気電子工学科 ₹ 158-8557 東京都世田谷区玉堤 1-28-1

TEL: (03)5707-0104 E-mail: yehara@tcu.ac.jp 
胞に沈着する[1]。

SPM を除去する技術として様々な集塵方式が 考案されている。集塵方式には重力集塵やサイク ロン集塵、スクラバー、スプレー塔、フィルタや 電気集塵装置 (Electrostatic Precipitator: ESP) な どがある。なかでも ESP は他の集じん装置と比 べて、圧力損失が小さく運転費用が安価、粒径 1 $\mu \mathrm{m}$ 以下の微粒子に対して集じん率が高いことが 利点である。したがって、火力発電所や工場など の産業用から自動車道路トンネル用、ビル空調用、 家庭用空気清浄器など多くの空気環境保全に役 立っている。本稿ではディーゼル排ガス中の PM を処理する技術として ESP を取り上げ、ESP 内の 粒子挙動や集塵特性、最新の技術動向について解 説する。

\section{2. 電気集塵理論}

一般に電気集塵における空間内の粒子に加わ る力とは電気的な力、拡散付着力、慣性力、重力 などが挙げられる。この中でも電気的な力が最も 大きく支配的となっている。これは、電気集塵で は粒子をコロナ放電で带電させ電界からのクー ロン力によって捕集するためである。ESP の外装 を Fig. 2 に示す。一般に ESP には一段式と二段 式があり、図には二段式を示した。二段式電気集 塵装置では帯電部と集塵部に分かれており、帯電 部でコロナ放電を発生させる。この放電により放 電極近傍で多数のイオンが発生し、イオンは接地 電極方向へ加速される。ここにPMが通過すると、 イオンとの衝突やイオンの熱拡散による衝突で PM は帯電される。帯電された粒子は平行平板を 形成する集塵部で、クーロン力によって電界方向 に引き寄せられ、接地電極へと捕集される。クー ロン力は次式で与えられる[2]。

$$
F_{c}=Q E_{c}=n e E_{c}
$$

$F_{\mathrm{c}}$ : クーロン力 $[\mathrm{N}] 、 Q$ : 電荷量 $[\mathrm{C}] 、 e:$ 電気 素量 $\left(1.6 \times 10^{-19}[\mathrm{C}]\right) 、 n$ : 電荷の数、 $E_{c}$ : 集塵部電 界強度 $[\mathrm{V} / \mathrm{m}]$

コロナ放電による粒子の帯電機構は、おもにイ オンの熱運動にもとづく拡散帯電とイオンの衝 突による電界帯電に分けられる。粒子の帯電量は 拡散帯電量と電界帯電量の和として(2)式で表さ れ、拡散帯電量 $q_{d}$ は(3) (5)式、電界帯電量 $q_{f}$ は (6)〜(8)式で表される[2,3]。

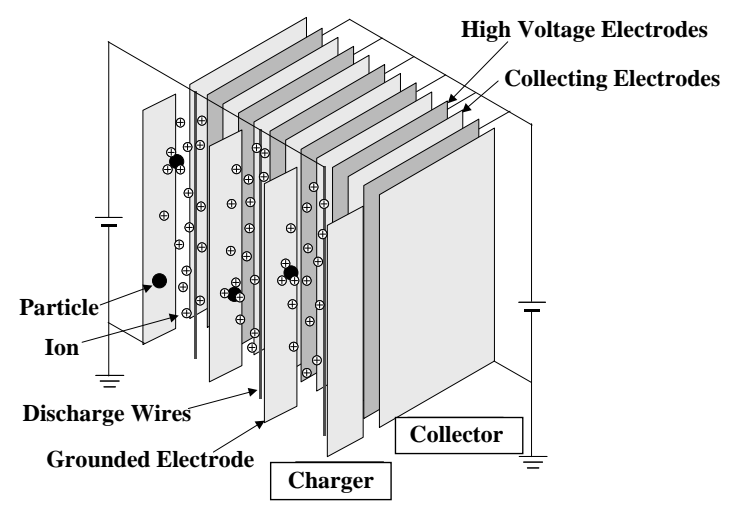

Fig. 2 Schematic of ESP.

$$
\begin{aligned}
& q=q_{d}+q_{f} \\
& q_{d}=q^{*} \ln \left(1+\frac{t}{\tau_{d}}\right) \\
& q^{*}=\frac{2 \pi \varepsilon_{0} d k T}{e} \\
& \tau_{d}=\frac{8 \pi \varepsilon_{0} k T}{d C_{i} n_{i} e^{2}}=\frac{8 \pi \varepsilon_{0} k T \mu_{i} E}{d C_{i} J_{i} e} \\
& q_{f}=\frac{q_{f s}\left(t / \tau_{f}\right)}{1+\left(t / \tau_{f}\right)} \\
& q_{f s}=\frac{3 \pi \varepsilon_{0} \varepsilon_{s} d^{2} E}{\varepsilon_{s}+2} \\
& \tau_{f}=\frac{4 \varepsilon_{0}}{\mu_{i} \rho_{i}}=\frac{4 \varepsilon_{0} E}{J_{i}}
\end{aligned}
$$

$q^{*}$ : 拡散帯電定数 $[\mathrm{C}] 、 t$ : 帯電時間 $[\mathrm{s}] 、 \tau_{d}$ : 拡 散帯電時定数 $[\mathrm{s}] 、 d:$ 粒子径 $[\mu \mathrm{m}] 、 \varepsilon_{0}:$ 真空の 誘電率 $8.85 \times 10^{-12}[\mathrm{~F} / \mathrm{m}] 、 k$ : Boltzmann 定数 $1.38 \times$ $10^{-23}[\mathrm{~J} / \mathrm{K}] 、 T$ : 絶対温度 $[\mathrm{K}] 、 C_{i}$ : イオンの平均 熱運動速度 $[\mathrm{m} / \mathrm{s}] 、 n_{i}$ : イオン密度 $\left[\mathrm{m}^{-3}\right] 、 \mu_{i}$ : イ オンの移動度 $\left[\mathrm{m}^{2} / \mathrm{Vs}\right]$ 正イオン: 0.00014、負イ オン : 0.00021、 $J_{i}$ :イオン電流密度 $\left[\mathrm{A} / \mathrm{m}^{2}\right] 、 \tau_{f}$ : 電界帯電時定数 $[\mathrm{s}] 、 q_{f s}$ : 飽和電界带電量 $[\mathrm{C}]$ 、 $\varepsilon_{S}$ : 粒子の比誘電率 5.5、 $\rho_{i}$ : 空間イオン電荷密 度 $\left[\mathrm{C} / \mathrm{m}^{3}\right]$

理論帯電量の粒径特性の例を Fig. 3 に示寸。拡 散帯電量および電界帯電量のいずれにおいても、 粒径が大きくなるに従い増加する。しかし、粒径 約 $0.15 \mu \mathrm{m}$ を境として、それ以下では拡散帯電、 
それ以上では電界帯電が優勢となる。

帯電部で帯電された粒子は集塵部にて集塵さ れる。この時、粒子には風速によるガス流方向の カとクーロン力による電界方向の力の合力によ つて電極に到達する。このクーロン力による電界 方向への移動速度 $W_{t h}$ は次式で示される[2,3]。

$$
\begin{aligned}
& W_{t h}=\frac{q E}{3 \pi \eta d} C_{m}[\mathrm{~m} / \mathrm{s}] \\
& C_{m}=1+2.54 \frac{\lambda}{2 d}+0.8 \frac{\lambda}{2 d} \exp \left\{-0.55\left(\frac{2 d}{\lambda}\right)\right\} \\
& \lambda=6.11 \times 10^{-8} \frac{T}{293} \times \frac{1}{p}
\end{aligned}
$$

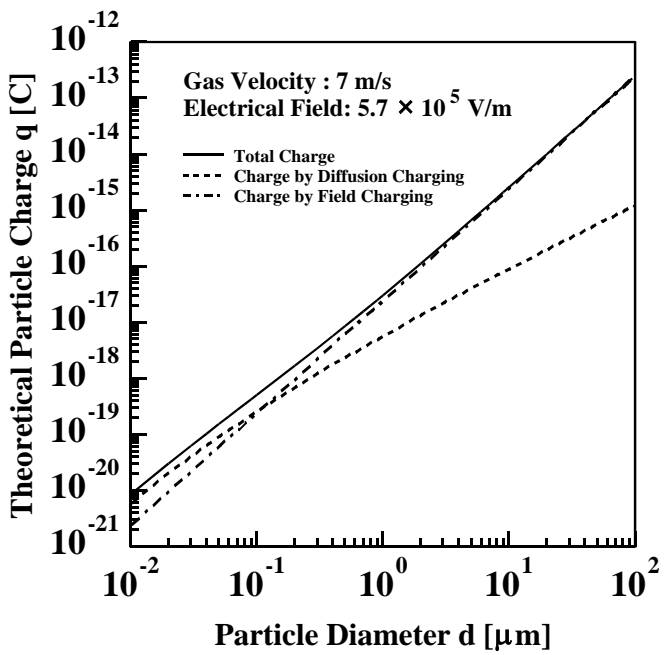

Fig. 3 Theoretical charge of particle.

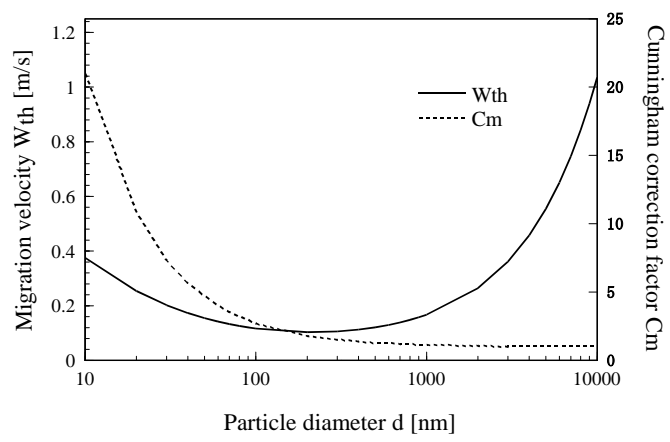

Fig. 4 Migration velocity and Cunningham correction.
$C_{m}$ はカニンガム補正係数、 $\eta$ は空気の粘性係数 $1.81 \times 10^{-6} \mathrm{Ns} / \mathrm{m}^{2} 、 P$ : ガス圧力 $[\mathrm{atm}]$

Fig. 4 に上式により計算した移動速度 $W_{t h}$ とカ ニンガムの補正係数 $C_{m}$ を示す。カニンガム補正 係数は粒径約 $1 \mu \mathrm{m}$ 以上においてはほぼ 1 である。 粒径が小さくなり、気体の平均自由行程程度にな ると粒子の表面での“すべり”を考慮する必要が ある。このため小さな粒子は通常よりも早く移動 するようになる。およそ $1 \mu \mathrm{m}$ 以下の場合に顕著 になるため粒子の移動速度はこの範囲で補正を 加える必要がある。これがカニンガムの補正係数 である。また粒子の電界方向への移動速度は Fig. 3 に示した帯電量に強く影響寸るため大きな粒 子の方が移動速度大きくなる。以上のことから粒 子の移動速度は $0.2 \mu \mathrm{m}$ 程度で最小值を持つこと になる。

上記の電界方向への移動速度を用いた集塵効 率の算出法がある。ESP を評価する上で、最も基 本的な集塵率 $\eta$ の算出法で Deutsch の理論式であ る。この式は ESP 内の同一断面積上において粒 子濃度が均一であるという仮定に基づくもので、 次式で示される[2,3]。

$\eta=1-\exp \left(-W_{t h} \frac{A}{Q}\right)=1-\exp \left(-W_{t h} \frac{l}{V_{g} G}\right)$

$A$ : 集塵電極総面積 $\left[\mathrm{m}^{2}\right] 、 Q$ : ガス流量 $[\mathrm{L} / \mathrm{s}]$ 、 $L:$ 集塵電極長 $[\mathrm{m}] 、 V_{g}:$ ガス風速 $[\mathrm{m} / \mathrm{s}] 、 G$ : 電極間ギャップ $[\mathrm{m}]$

集塵部に流入した帯電粒子は移動速度 $W_{t h}$ で電 極方向へ引き寄せられる。集塵電極に到達した粒 子を集塵されたものとするため、ガス中の粒子の 個数と集塵電極に到達した粒子の割合から集塵 率を求めることが出来る。このため集塵率は $W_{t h}$ が大きいほど高くなる。

集じん部にガス流速 $V_{g}$ で入った帯電粒子は、 集じん部の静電界からクーロン力を受けて集じ 几電極方向に速度成分 $W_{t h}$ で移動する。全粒子内 の集塵電極に補された割合を集塵効率 $\eta$ と定義 するので、速度成分 $W_{t h}$ が大きいほど集塵が容易 であるといえる。逆にガス流速 $V_{g}$ が大きいほど 集塵効率は低下寸る。風速 10～25 m/s における理 論集塵率の粒径特性を Fig. 5 に示す。どの風速に おいても粒径が $200 \mathrm{~nm}$ 付近で、集塵率は最小值 を持つ。これは粒径が小さくなると帯電量 $q$ は小 さくなるが、カニンガムの補正係数 $C_{m}$ は大きく なる。逆に粒径が大きくなると $q$ は大きくなるが、 
$C_{m}$ は 1 に近付く。よって粒径が $200 \mathrm{~nm}$ 付近で集 塵率が最小となる。風速を $10 \mathrm{~m} / \mathrm{s}$ から $25 \mathrm{~m} / \mathrm{s}$ に 上げると、200 nm 付近では集じん率が 35\%程度、 低下することになる。

次にディーゼルエンジンから排ガスを実際に ESP で集塵した例を示す。処理風速を変化させ、 集塵率を測定した結果を Fig. 6 に示す。粒径 100 $\mathrm{nm}$ 程度で、集じん率は最小になっている。この 結果は、Fig. 5 に示した理論集塵率とほぼ一致し ている。また、風速を増加させると集塵率が減少 することがわかる。特に、風速 $25 \mathrm{~m} / \mathrm{s}$ 時では $60 \%$ を下回る粒径範囲も存在し、集塵率の低下が認め られる。しかしながら、実験值の集塵率はどの流 速においても、理論集塵率の值より高い。この理 由としては、理論集塵率の計算には帯電部におけ る捕集を考慮していないことが主要因だと考え られる。

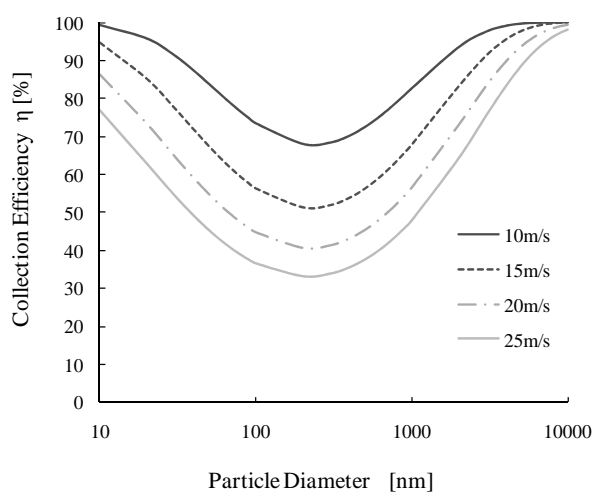

Fig. 5 Theoretical collection efficiency. Discharge current $2.5 \mathrm{~mA}$, Collection voltage DC-7.0 kV.

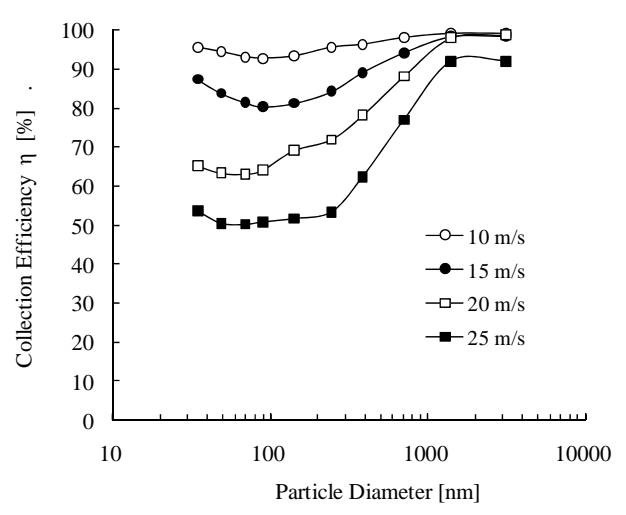

Fig. 6 Collection efficiency for various gas.

\section{3. 電気流体力学}

電気流体力学 (Electrohydrodynamicis : EHD) は、 流体中に外部電界または電流による電気力が作 用して流動を発生する現象である[4]。この現象を 電場と流れ場と温度場という観点からとらえる と、考えられる相互作用は数多くある[5]。各作用 力のオーダーを比較すると、電場を決める要因と して、流れ場の影響を受ける対流電流分は、伝導 電流に比べて 1 桁小さいので第一近似として省 略できることから、電場のみで決まる伝導電流が 主要となる。流れ場を決める要因としては、イオ ンに働くクーロン力が大きく、浮力や分極に働く 電気力は省略できる。また、温度場を決める要因 としては、イオン風による強制対流が主要となる。

イオン風のメカニズムを Fig. 7 に示す。鋸歯対 平板の電極構造において、負極性の高電圧を印加 すると負極性コロナ放電が発生する。それより生 じた負イオンが途中で再結合することなく電界 の作用により平板電極へと向かう。その間に中性 分子と衝突し、運動エネルギーを中性分子に与え る。その結果、イオンならびに中性分子は平板電 極へ向かって移動し、移動により発生した流動を イオン風という。EHD 的特性速度は式(13)で与え られる[6]。

$$
U_{E H D}=\sqrt{\frac{D J_{P}}{\mu \rho_{g}}}
$$

$J_{p}$ :集じん電極上の最大電流密度、 $D$ : 電極間距離、 $\rho_{g}$ : ガス密度、 $\mu$ :イオン移動度

正極性直流、負極性直流、交流 $(60 \mathrm{~Hz})$ 印加時 の、鋸歯直下の最大イオン風とコロナ電流の平方 根との関係を見ると、交流<負極性<正極性の関係

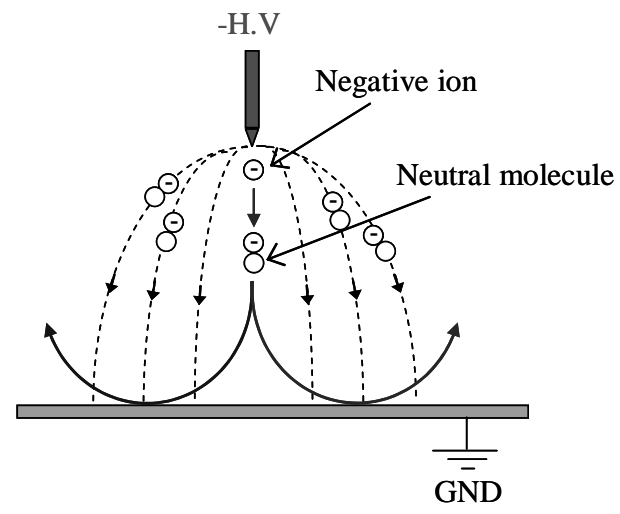

Fig. 7 Ionic wind. 
である。

ESP 内の流れ場の研究は以前より多くなされ ており[7-11]、イオン風を可視化する研究も多い [12]。Fig. 8 に著者らが行った、シュリーレン法 による ESP 内の流れ場の結果を示す。(a)は従来 型 ESP で針対平板の電極構成である。中心の黒 い円が電極位置を示している。左から 2 本の流線 が観察され、放電極の直下でイオン風の影響がみ られる。(b)は著者らが考案した EHD を活用した ESP である。平板電極上に捕集用のポケットを設 けている。また、前段のポケットに向かってイオ ン風が発生するため、主流体は平板電極方向に曲 げられ、粒子をポケットに導いている。

実際のディーゼルエンジンを稼働させ, その排 ガスを処理した際の集應率の粒径特性（20-500 $\mathrm{nm}$ ）例を Fig. 9 に示す。従来型 ESP、EHD ESP 共に $90 \%$ 以上の高い効率であるが、EHD ESP の
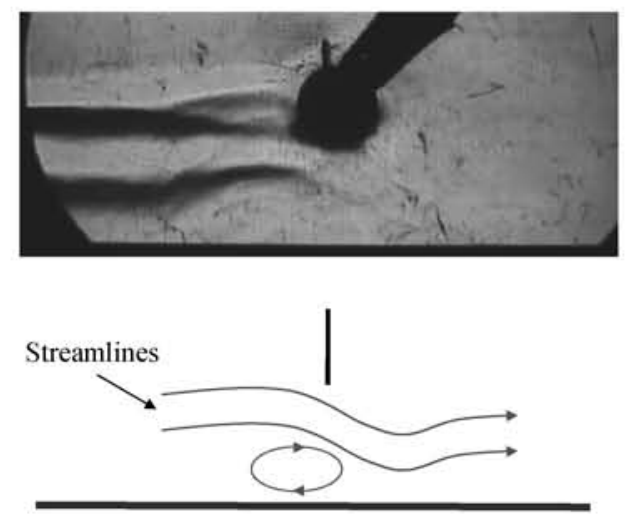

(a) Conventional ESP.
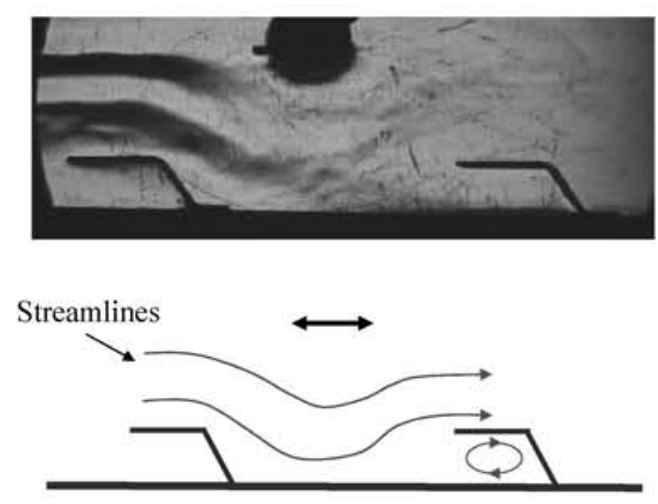

(b) EHD ESP.

Fig. 8 Schlieren image of ionic wind.

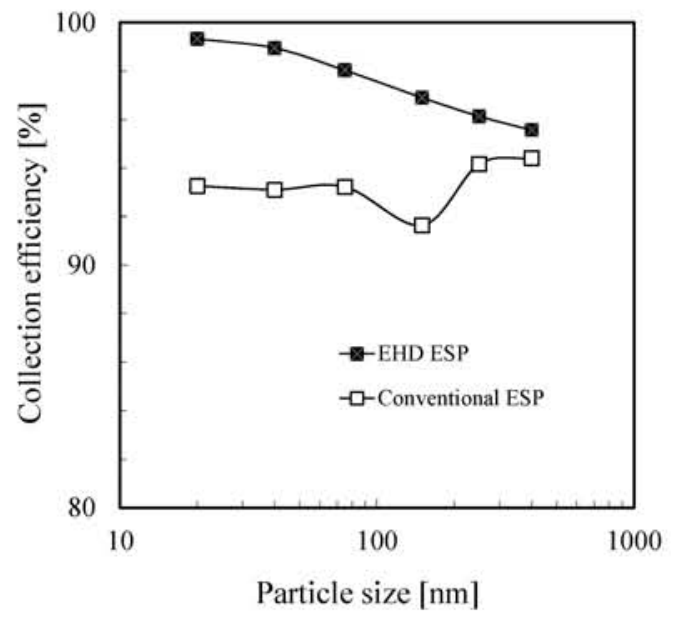

Fig. 9 Particle size-dependent collection efficiency.

方がより高い集塵率を示している。このように EHD を有効利用して、集塵率の向上が図られて いる[13]。

\section{4. 再飛散現象}

ESP の性能は捕集粒子の見掛けの電気抵抗率 に大きく依存する。抵抗率が約 $10^{4} \Omega \mathrm{cm}$ 以下では 集應極に捕集された粒子が、再び集應電極から飛 び出す再飛散現象が起こる。一方、抵抗率が約 $10^{11} \Omega \mathrm{cm}$ 以上では堆積した粒子層にコロナ電流 が流れることで高電界が形成され、粒子層の絶縁 破壊が生じる。すると、放電空間に放電極からの イオンと逆極性のイオンが放出され粒子の帯電 を阻害し、また火花電圧值が大幅に低下寸る。こ のため集應効率が大幅に低減する。これが逆電碓 現象である。逆電離を抑制するため、ガスの調質 あるいはガス温度を高くして粒子の見掛けの電 気抵抗率を下げたり、パルス電圧を用いてコロナ 電流分布を均一化することなどが行われている [2]。

ディーゼルエンジンから排出されるPMの主成 分はカーボンであり、カーボンのような電気抵抗 の低い粒子 $\left(\rho<10^{3} \Omega \mathrm{cm}\right)$ を捕集する場合、ESP で は再飛散現象が問題となる。再飛散現象について、 その原理や再飛散粒子を再捕集する研究例 $[14,15]$ はいくつかあるが、再飛散を防止する研究 はあまり見かけない。著者等が行ってきた再飛散 に関する研究は、(1)発生原理、(2)二次的問題、(3) 防止方法に大別でき，以下に概説する。 
先ず、(1)の発生原理について述べる。带電部で 負極性に荷電し、直流の負極性電圧を印加した集 塵部における電極上のSEM 写真を Fig. 10 に示 す。接地電極の粒子の捕集状態は数珠状になって おり、高電圧電極にも捕集されている。粒子は負 極性に帯電されているため、高電圧電極には粒子 は捕集されないはずである。これは、再飛散によ り起こった現象である。

直流電圧を印加した時の再飛散現象のモデル を同図に示す。モデルの各ステップは、次のよう なプロセスで進むと考えている。

（A）带電部で負極性に帯電した粒子は、集 じん部の接地電極に捕集される。捕集され た粒子は、抵抗率が低いと直ちに負電荷を 失い, 静電誘導により逆極性に带電し正極 性に誘導带電する。

（B）捕集された粒子は、極板上の粒子と凝集し、 極板上で数珠状に連なる。数珠粒子はガス 流の影響を受け、流体抗力が増加する。ま た、これらの粒子は静電誘導により捕集電 極と同極性であるので、クーロン力により 対向電極に引き付けられる。この 2 つの要 因により付着力より剥離力のほうが大き くなり、凝集粒子の再飛散現象が発生する。

(C) 再飛散現象が発生することにより、高電圧 電極にも再飛散粒子が捕集される。集じん 部後方に流出する粒子も多くあるので、大 粒径粒子の集じん率が低下する。

以上のことから、集じん部に直流電圧を印加する と捕集状態は数珠状になり、再飛散現象が発生し、 大粒径粒子の集塵率が低下することになる。

実際にディーゼルエンジン排ガスを大気で混 合希䣋し、2 段式ESP で集塺した場合、再飛散現 象が確認される。この場合、粒径 $0.3 \sim 0.5 \mu \mathrm{m}$ で は、時間の経過に対して集塵率はほぼ一定である。 しかし、粒径 $2.0 \mu \mathrm{m}$ 以上の大粒径粒子の集塺率 は、稼働時間とともに低下寸る。さらに粒径 5.0 $\mu \mathrm{m}$ 以上では、運転時間の経過とともに集じん率 は低下し、ESP 上流の濃度より下流の方が高くな る。これは微小粒子が凝集し、大粒径の粒子とな って飛散するからである。

(2)の二次的問題では再飛散現象は、集塵率の低 下の原因[16] となる。そして高速道路トンネル内 に ESP が設置されると、再飛散粒子は自動車運 転者の視環境に影響を与える。さらに、再飛散粒

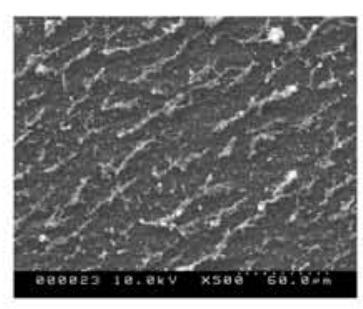

(a) GND

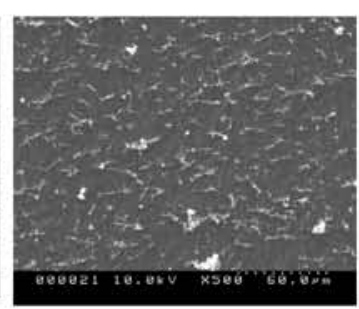

(b) H.V.

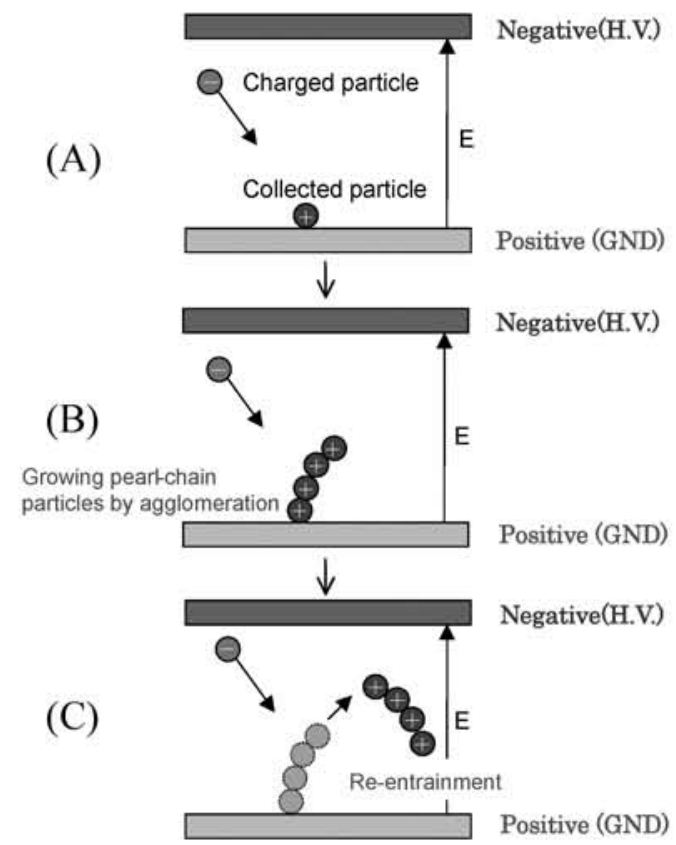

Fig. 10 Process of reentrainment.

子は、ESP 下流壁面に付着[17] し、壁面污染の原 因になるとも考えられている。

(3)については、著者等は主に次の防止方法を提 案してきた。粒子間および粒子と集塵電極間の付 着力の増加により再飛散を抑制できると考え、処 理ガス中への水分噴霧を試みた。ディーゼルエン ジン排ガス中の PM は疎水性のカーボンである ため、水噴霧形 ESP では界面活性剂が入った水 溶液を噴霧すると、大粒径粒子の集塺率が向上し、 再飛散の抑制が確認された[18]。

再飛散の発生は、集塵粒子が接地電極と同極性 となることが原因の一つである。このことに着目 し、集應電極表面を誘電体で覆った、絶縁被覆形 ESP の開発を行った。再飛散抑制メカニズムは次 のとおりである。集塵部において、帯電粒子は接 
地平板電極を被覆している絶縁体表面に捕集さ れる。絶縁体表面に集じんされた粒子は電荷が保 持されるため、付着力として静電気力が働く。こ の静電気力によって再飛散が抑制される。この効 果は、ポリエチレンシートで覆った電極を使用し た実験において実証されている[19]。

また、集塺電極に捕集され凝集する粒子の形状 を変化させ、粒子と集應電極の接触面積を増加さ せることで、再飛散を防止できないかと考えた。 この考えを基にして、集塵部に交流電圧を印加す ることで、再飛散の抑制を試みた[20,21]。従来型 の直流電圧を集塺電極に印加した ESP では、再 飛散現象のため稼動後 10〜30 分で集じん率が低 下してしまう。しかしながら、交流 ESP では、 稼動後 300 分以上経過しても、粒径 $0.3 \sim 10 \mu \mathrm{m}$ において集じん率の低下は見られない。

交流 ESP における集塺電極板上の捕集粒子の SEM 画像を Fig. 11 に示寸。直流電圧を印加し た ESP では、先に示したような数珠状の極板凝 集粒子が多数観測されるのに対し、交流 ESP で は数珠状凝集粒子は観測されず, 粒子は球状とな っている。

ここで、交流 ESP における再飛散抑制モデル を同図に示寸。

（A）带電部で負極性に帯電した粒子は、接地 極に集應され、直流電圧印加時と同様に、 静電気力により数珠状の凝集粒子を形成 する。

（B）集塺電極に印加している電圧は交流であり、 極性の変化がある。極性反転した時に、接 地電極上の凝集粒子は捕集電極に引き寄 せられ、数珠状から球状に変化する。

(C) 極板凝集粒子は極性が変化する度に球状化 し、電極との接触面積が増加する。一定周 期でこれを繰り返し、極板凝集粒子が球状 化するため、接触面積が増加し再飛散は抑 制制される。

このようにして、電極上に捕集した粒子は流体 抗力やクーロン力を受けにくくなり、再飛散現象 を抑制できる。また、帯電粒子は高圧・接地の両 極板上でほぼ同量捕集される。交流形 ESP は他 の再飛散防止対策に比べ電源電圧を変化するだ けであり、その効果も大きい。この交流形 ESP は 2004 年に、2つの自動車道路トンネルの換気設備 で実用化されており、有効な結果が得られている。

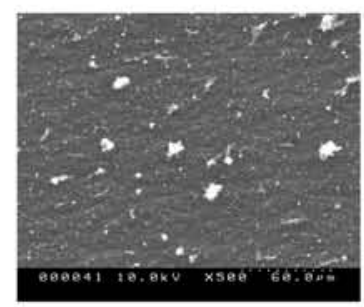

(a) GND

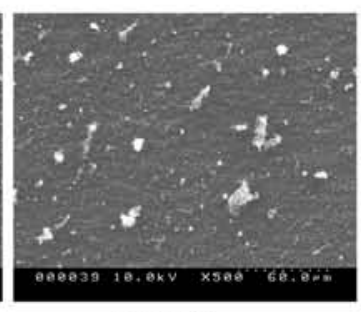

(b) H.V.
(A)

(B)

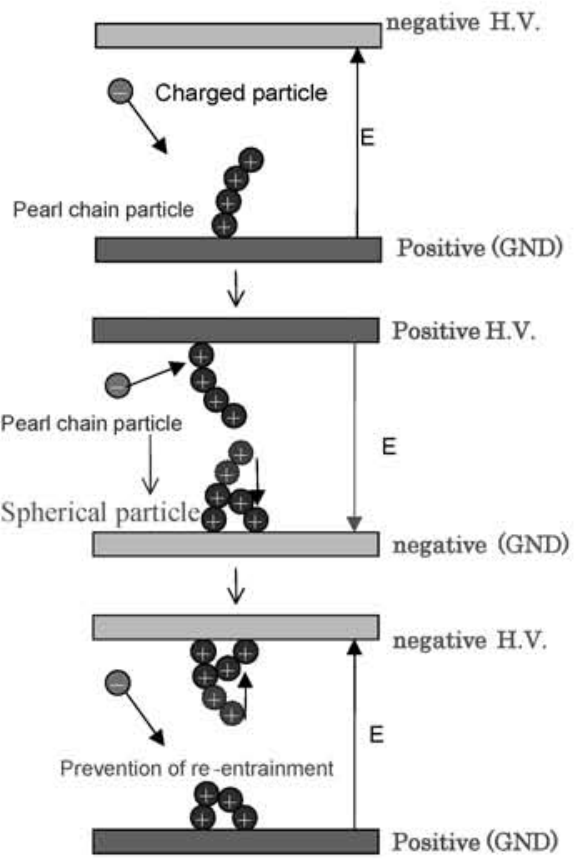

Fig. 11 Prevention of reentrainment using AC ESP.

\section{5. おわりに}

近年, 海洋污染問題は国際的に問題視されて おり，舶用ディーゼル機関から排気される有害 物質低減技術の確立は熱望され国際的な緊急 課題である。船舶用ディーゼルエンジンの排出 ガスには主に PM やNOx, SOx などの大気污染 物質が含まれている。船舶からの大気污染物質 の排出規制については，国際海事機関で審議さ れ, 2005 年 5 月 MARPOL 条約付属書VIが発効 され(Tier1), 2011 年からの 2 次規制(Tier2)を経 て, 2016 年からは 3 次規制(Tier3)として NOx では Tier1 比で 80\%削減が求められている。船 舶の始動低温時には大量の PM が発生し、NOx 
の発生は PM とトレードオフの関係にある。

自動車用ディーゼルエンジンから排出される PM については，ディーゼルパティキュレートフ イルタが主流である。しかし，舶用エンジンか らの排ガス量は多く, PM 濃度が高いためフィル 夕による $\mathrm{PM}$ 捕集はその再生方法 $\left(600^{\circ} \mathrm{C}\right.$ 以上の 燃焼法, $\mathrm{NO}_{2}$ や触媒による $300^{\circ} \mathrm{C}$ 以上の燃焼法) が非常に高価となり実用的ではない。電気集塵装 置は他の集塵装置と比べて, 圧力損失が小さいな どの利点を持ち, 粒径 $1 \mu \mathrm{m}$ 以下の微粒子に対し て集塵率が高い。この利点を生かし舶用ディーゼ ルエンジンからの排ガス処理に ESP が注目され ている。現在, 著者らも船舶からの排ガス処理に 適応可能な ESP を研究・開発中であり, ゼロエ ミッションを視野に入れ省エネルギー化の観点 からも検討を行っている。

\section{参考文献}

[1] Annals of the ICRP, Human Respiratory Tract Model for Radiological Protection, A Report of a Task Group of the ICRP. (1994).

[2] Handbook of Electrostatics, Ohmsha (1981).

[3] Hinds, W., Aerosol Technology, Inoue Shoin (1985).

[4] Zhao, L. and Adamiak, K., Effects of EHD and External Airflows on Electric Corona Discharge in Point-Plane/Mesh Configurations, IEEE Trans. Ind. Applications, Vol.45(1), 16-21 (2009).

[5] Handbook of Electrostatics, Ohmsha. (1998).

[6] Adachi, T. and Kawasaki, M., Ionic Wind Due to Corona Discharging, Proc. Inst. Electostat. Jpn., Vol.11(4), 246-254 (1987).

[7] Adachi, T., Kawasaki, M. and Nakabayashi, H., The Behavior of Dust Particle in Electrostatic Precipitators, Proc. Inst. Electostat. Jpn., Vol.4(3), 152-159 (1980).

[8] Yamamoto, T. and Velkoff, H.R., ElectroHydrodynamics in an Electrostatic Precipitator, J. of Fluid Mechanics, Vol. 108, 1-18 (1981).

[9] Watanabe, T., Improvement of Electrostatic Precipitation Technology with Aid of Computer Simulation, Proc. Inst. Electostat. Jpn., Vol.10(6), 477-480 (1986).

[10] Motegi, K., Abe, K., Ohkubo, T. and Nomoto, Y., The Effect of Wire Net Electrode on Flow Field in Duct Type Electrostatic Precipitator, Proc. Inst. Electostat. Jpn., Vol.22(5), 262-267 (1998).

[11] Adachi, T., Ionic Wind in the Electrostatic Precipitator-Experimental Treatment by the Schlieren Method, Trans. IEEJ., Vol.93(7), 273-280 (1973).
[12] Fujishima, H., Ueda, Y. and Tomimatsu, K., Numerical and Experimental Investigation of Electrohydrodynamics in Electrostatic Precipitator, J. Inst. Electrostat. Jpn., Vol.28(4), 218-223 (2004).

[13] Yamamoto, T., Mimura, T., Otsuka, N., Ito, Y., Ehara, Y. and Zukera, A., Diesel PM Collection for Marine and Automobile Emissions Using EHD Electrostatic Precipitators, IEEE Trans. Ind. App., Vol.46 (4), 1606 - 1612 (2010).

[14] Masuda, S., Moon, J.D. and Aoi, K., AUT-AINER Precipitator System - an Effective Control Means for Diesel Engine Particulates, Actas 5, Congreso Int Aire Pure 1980 Tomo 2, 1149-1153 (1982).

[15] Matsusaka, S., Shimizu, M. and Masuda, H., Formation of Wall Particle Layers by Simultaneous Deposition and Reentrainment of Fine Particles in Turbulent Aerosol Flows, J. of Chemical Eng. of Jpn., Vol.19(2), 251-257 (1993).

[16] Zukeran, A., Ikeda, Y., Ehara, Y., Ito, T., Takahashi, T., Kawakami, H. and Takamatsu, T., Two-Stage Type Electrostatic Precipitator Re-entrainment Phenomena under Diesel Flue Gases, IEEE Trans. Ind. Applicat., Vol.35(2), (1999).

[17] Takahashi, T., Takamatsu, T., Kawakami, K., Zukeran, A., Fujimura, H., Ehara, Y. and Ito, T., Particle Deposit on the Surface of the Wall by Electrostatic Precipitator, J. Inst. Elect. Install. Engnr. Jpn., Vol.18(12), 853-859 (1998).

[18] Zukeran, A., Jindai, W., Kawada, Y., Ehara, Y., Ito, T., Takahashi, T., Kawakami, K. and Takamatsu, T., Effect of Surfactant on Re-entrainment Phenomena in an Electrostatic Precipitator, Trans. IEEJ., A, Vol.119(3), 254260 (1999).

[19] Takahashi, T., Kawada, Y., Zukeran, A., Ehara, Y., and Ito, T., Inhibitory Effect of Coating Electrode with Dielectric Sheets on Re-entrainment in Electrostatic Precipitator, J. Aerosol Sci., Vol.29(1), S485-S486 (1998).

[20] Kawada, Y., Kubo, T., Ehara, Y., Takahashi, T. Ito, T., Zukeran, A., Kono, Y. and Yasumoto, K., The Prevention of Particle Re-entrainment Phenomena in Electrostatic Precipitator with AC Wave, Trans. IEEJ., A, Vol.122(9), 811-816 (2002).

[21] Zukeran, A., Kawada, Y., Kono, Y., Yasumoto, K. and Ito, T., Performance of an Electrostatic Precipitator Applied Rectangular AC Electric Field for Prevention of Particle Re-Entrainment Phenomena, Safety in Road and Rail Tunnnels (2003). 